\title{
The concept of health - in the history of medicine and in the writings of Hahnemann ${ }^{\text {ir }}$
}

\author{
Josef M Schmidt* \\ Department of the History of Medicine, Ludwig-Maximilians-University of Munich, Germany
}

\begin{abstract}
The number of notions of health is not infinite. In the history of medicine we can only find a number of different conceptions or paradigmatic ideas of health, in a variety of references and combinations. Health was seen as: 1. harmonious balance between principles or entities, 2. result of a struggle against opposing forces, 3 . continuous dialectical process, 4. hierarchy of components or functions, 5. potential to perform and to develop, 6. transcendence towards higher levels of being, 7. result of conscious autonomous action, 8. optimal causal functioning, or 9 . public task and responsibility.

Hahnemann's view of health, as reflected in his writings, utilized virtually all of these elements. They reappear for instance as: 1 . harmonious tuning of the life force, 2 . defeat of pathogenetic influences, 3. admittance of aggravations, 4. autocracy of the spirit-like life principle, 5 . reference to a higher goal of human existence, 6 . perfecting character of medical service, 7. concern about dietetics and life style, 8. utilization of causality and natural science, and 9. appealing to governmental provisions and medical police.

These paradigms have been repeatedly recombined and applied. The theory of medicine is the attempt to analyze, adjust, and develop concepts that meet the demand of contemporary medical practice. Medical theory lies between the fields of observable facts and metaphysical convictions. Distinguishing the levels of practice, theory, and metaphysics could allow the open discussion of theoretical issues, such as the concept of health or disease, without raising purely theoretical objections to well-established practice. Homeopathy (2010) 99, 215-220.
\end{abstract}

Keywords: Notion of health; History of medicine; Samuel Hahnemann; Homeopathy; Theory of medicine

\section{Introduction}

Considering the precarious condition of human existence, vulnerable, dependent on, and susceptible to, a many and variable influences, the desire for and appreciation of an undisturbed and steady state of good health seems to be quite natural and an anthropological constant. In fact, throughout the ages people have strived to secure, protect, and restore - or even to enhance and prolong - the precious moments of well being that they may have experienced from time to

\footnotetext{
${ }^{4}$ Revised version of a paper presented at the 64th Congress of the Liga Medicorum Homoeopathica Internationalis in Warsaw, Poland, on 27 August 2009.

* Correspondence: Josef M Schmidt, Department of the History of Medicine, Ludwig-Maximilians-University of Munich (LMU), Lessingstr. 2, 80336 Munich, Germany.

E-mail: j.m.schmidt@Irz.uni-muenchen.de

Received 27 November 2009; revised 6 April 2010; accepted 22 May 2010
}

time amidst their ordinary troubled lives. Accordingly, medicine was invented and developed to prevent, relieve, and cure diseases, to reduce or eliminate, as far as possible, any impairment or injury to health.

In modern times, the demands of patients and claims of doctors towards the optimum state of health, have increased considerably. People are no longer content with being or becoming relatively healthy after medical treatment, but instead want to become healthier or attain the healthiest state possible. After all, who would refrain from having a bigger house, a faster car, or a higher salary - if he could choose? Yet, contrary to measurable things that can be compared quantitatively, for health there is no uniform scale for assessing what is to be considered good, better, or best health. On the contrary, everything depends on the conceptual framework which underlies this notion. That is why people do not necessarily mean the same thing when they talk about health. 


\section{History of medicine}

In the history of medicine, we can find very different approaches as to how people of different cultures and periods tried to conceptualize what they envisaged as a healthy state of being. Interestingly, the number of concepts to be found in all sources is not infinite, but relatively limited, if examined systematically. There are just a couple of principles humans use to delineate in theoretical terms what they have in mind when they think of health. Analyzed thus, relevant statements from medical doctrines (including Hahnemann's homeopathy) consist only of specific combinations of these recurring paradigms.

1. One of the oldest and still current paradigms is the concept of health as a state of harmony - in the broadest sense. This basic pattern of thinking may be applied to a variety of relations, depending on the underlying ontology. Referring for instance to one's relationship to Gods or ancestors (as in prehistoric and ancient cultures), healthy living would mean a life pleasing to God or to be on good terms with the deceased. ${ }^{1}$ The same paradigm of harmony, however, can be used with reference to the individual's relationship to society, her/his family, or partner (as in modern bio-psycho-social models of health), ${ }^{2}$ to the environment (as in ecological models) or to the cosmos as a whole (as in medieval models of correspondence between microcosm and macrocosm). Or the focus of the paradigm is on the relationship between body and soul (as in psychosomatics), different parts of the body (like the Hippocratic humours, the four classical qualities, or the modern atoms and molecules), or functions of the body (like incitability and excitement, as in Brownianism; spasm and atony, as in the doctrine of William Cullen; or the distribution of a nervous fluidum, as in Mesmerism). ${ }^{3}$ Ultimately, even the modern concept of "steady state' is based on the idea of a harmony between incoming and outgoing fluxes. In all these variations of the concept of health as harmony, therapy comes down to an impulse to achieve harmonization, balance, or compensation.

2. Opposed to this way of thinking, health can also be imagined as the result of struggle. Again, depending on the underlying ontology, the fundamental struggle can be assumed to take place between Gods and demons (as between Ahura Mazda and Ahriman, as in the ancient Persian religion of Zoroastrianism), ${ }^{4}$ or between psychic, religious, or political influences (as in the guarding against foreign infiltration, as in concepts of national health in the nineteenth and twentieth century). The same paradigm is also the basic thought of all versions of germ theory, whether concerning worms and parasites or bacteria, viruses, etc. The therapeutic strategy in all these cases is the attempt to overcome, defeat, or eliminate the corresponding adversary. Health is the final victory over the threatening agent.

3. Unlike these opposite paradigms, health can also be seen as a dialectical process: without knowing of disease we could not even think about health. Visualizing a continuous scale with the two extreme points health and disease, the most common state would evidently be a mixture of both, i.e. neither being totally healthy nor totally ill. The first to propose this concept were the Alexandrian physicians Heróphilos and Erasístratos (third century BCE). Other great thinkers emphasized a positive, relative, or pedagogical value of illness, for instance for the perfection of the art of living or the development of heart and soul (such as Goethe and Novalis). ${ }^{5}$ The German mystic Eckhart called disease the golden path (via aurea) to real health, i.e. health in God. Among the Bohemians of the nineteenth and twentieth century disease was even, in a sense, glorified since it was believed to be a precondition for artistic creativity. Similarly, in esoteric circles inspired by the New Age movement, illness is not seen as a useless disaster, but rather as a chance and a help for future spiritual growth.

4. Another vision of health is the concept of a hierarchical order. For example an advocate of ancient Greek democracy, Alkmaion of Croton, defined health as a state of isonomy, i.e. equal rule by all constituents of the organism, while monarchia, i.e. the predominance of one single party, he considered to be a disease. For Plato, however, health was the supremacy of the soul over the body, and, within the three parts of the soul, supremacy of the rational part over the desirous one. Hegel's notion of health implied the subordination of the anorganic under the organic, and Hufeland's concept of life force again meant its mastery over the physical organism. Strictly speaking, theories of proportion, symmetry, or beauty are all based on the idea of a graduated hierarchy of relevant parts. The same applies to the ancient Egyptian term 'ma'at', which implied justice in the political sphere as well as health in the sphere of medicine. ${ }^{6}$

5 . Health as potentiality is a concept derived from the lifeworld of craftsmen in the Greek polis. For Aristotle motion was the actualization of a potentiality or capability. Thus, health can be seen as the presupposition of one's ability to move or to accomplish something. The healthier one is, the more possibilities and options one has. In this sense, Hildegard of Bingen for instance called health a 'greenness' (viriditas). ${ }^{7}$ In German Idealism health was taken as an equivalent to freedom of the mind. In the context of military service health means fit to fight, and in the labour market to be fit for work. For Nietzsche health was the potential for augmentation, enhancement, and transgression. In general, being healthy in the sense of disposing of high potentiality should be recognizable for instance in longevity, optimism, and cheerfulness.

6 . The heading health as transcendence comprises all religious, spiritual, mystic, or ascetic concepts of health. For the Greek philosopher Diogenes for instance the healthiest life and behaviour consisted of asceticism. For the Stoics a kind of dispassion (apatheía) and for Epicurus calmness of the mind (ataraxía) was the 
healthiest state of the soul. Marcus Aurelius aspired to tranquility of the soul (tranquillitas animi) through selfcontrol. In the early Christian movement of 'Christus medicus' health was perceived as nearness to God and people tried to achieve this state through imitation of Christ. The famous Persian physician and philosopher Avicenna declared that healing of the soul is only possible through understanding. In the Renaissance a so-called 'body of grace' was sought through mystic intensification, and some women mystics exulted in pain, suffering, and bleeding, because these were venerated as 'darts of Christ' in their own body, through which they would get closer to him and become spiritually healthy. ${ }^{8}$

7. Health as autonomy indicates that health can also be interpreted as the result of conscious action, taking responsibility for oneself. This approach can be traced back to antiquity when health was conceptualized as a virtue by writers such as Aristotle, Cicero, or Seneca: a direct result of one's own self-control and temperance. According to Renaissance educational literature, health was the result of wisdom and education of the paterfamilias. Alternatively health was comprehended as a result of complying with special dietary regimes (as in early Islamic culture), a solitary and contemplative life (vita solitaria et contemplativa, as with Petrarch), ${ }^{9}$ or the appeal to a moral life (as with Ulrich von Hutten).

8. The paradigm differing most from the ones mentioned so far, is that of causality. From time immemorial humans had thought and conducted research in terms of causality, including medicine. Galen for example distinguished between healthy, unhealthy, and neutral causes (causae salubres, insalubres, neutrae). Also Renaissance magical techniques implied a good deal of causal thinking. This paradigm however developed an entirely new form with the scientific revolution of the seventeenth century, when causal-mechanical and quantitative reasoning became the basic paradigm of science par excellence. ${ }^{10}$ In medicine, this kind of reductionistic rationality did not breakthrough until nineteenth century, but since then has thrust all other approaches into the background. It limits itself to the investigation of the interplay of material structures of the body. On these premises, health is something like the most efficient and economical course of physical and chemical actions.

9. Influenced by the paradigms causality and autonomy, governments took measures to improve the health of the citizens. In the eighteenth century the public health movement started, with health legislation, organization, and 'health police'. Health education was promoted, and health catechisms were printed. Kant proclaimed health as a duty because it promotes morality. ${ }^{11}$ The political background of the new governmental efforts towards health, however, was utilitarianism and mercantilism. In the same spirit new sciences were introduced, for instance sociology as 'social phys- ics' (by Auguste Comte) and hygiene as 'doctrine of science of health' (by Max von Pettenkofer). In Germany the medical curriculum was reformed by legislation: from 1861 the philosophical exam was dropped and substituted by an intermediate test in natural sciences (tentamen physicum). ${ }^{12}$

10. At all times, beside the mainstream there were tributary streams as well. This is especially true for post-modernity in which a multitude of currents co-exist simultaneously. In the medical market for instance a plurality or broad variety of alternative concepts of health are offered. ${ }^{13}$ But each includes a combination of the basic paradigms mentioned above. They may be inspired by insights of quantum physics, systems theory, chaos research, theory of self-organization, autopoiesis, etc. and recombined among each other. The existence and attraction of such theories to a considerable part of the population indicate that simple causal-mechanical thinking, as predominating in modern medicine, does not sufficiently explain phenomena of the life-world of patients including their conceptions of health. Hence, in the 21st century there is still a need to refer to the other, seemingly outdated, paradigms as well.

\section{The writings of Hahnemann}

Samuel Hahnemann (1755-1843) lived before the triumphant advance of the scientific method within medicine in the nineteenth century had reduced the art of healing to a paradigmatic monoculture. In his day it was still possible for protagonists of medicine to avail themselves of a very broad spectrum of concepts. In fact, the professional discussions of that period (German Idealism and German Romanticism) are full of reminiscences of all the paradigms mentioned here. ${ }^{14}$ Also Hahnemann was open to and familiar with all of them.

1. As to the concept of health as harmony for instance it is obvious to refer to Hahnemann's well-known definition of disease as a derangement of the life force, ${ }^{15}$ which has its parallel in the conception of health as a state of harmonious tuning of the life force. Indeed, the very idea of tuning does not make sense without a basic concept of harmony. Correspondingly, at various places in the 'Organon of Medicine' Hahnemann paraphrases health in terms of a 'harmonious course of life' or 'harmonious play of life'. ${ }^{16}$

2. Health as a result of struggle, on the other hand, is another constant idea pervading Hahnemann's writings from the beginning. He describes many pathogenetic influences, against which the organism has to protect and defend itself. The spectrum ranges from physical, climatic, and geographical to mental, emotional, and imaginary influences up to the pathogens of acute and chronic infectious diseases. Since in Hahnemann's day bacteria, viruses, and most protozoa were unknown, he used less sharply defined terms, such as contagion, miasm, or just 'tinder of infection'. ${ }^{17}$ In any 
case, according to this concept, the mission of medicine is to help patients to overcome and defeat the hostile intruders, as for instance in cholera.

3. Interestingly, Hahnemann's vision of the interaction between organism and pathogenetic agents (or medicinal substances) was not confined to a simple alternative, such as victory or defeat, but also implied dialectical elements. His concept of aggravation for example rests on the presupposition that a (temporal) deterioration of symptoms need not necessarily mean a worsening of the state of health. On the contrary, an addition of complaints and ailments under therapy can be a sign of a restitution process and finally lead to a better state of health than before. ${ }^{18}$ The same applies to drug proving which, according to Hahnemann, has a roborant effect on the prover. ${ }^{19}$

4. Despite emancipatory movements, such as the French Revolution, hierarchical thinking was still very common in Hahnemann's day. Hence, to medical thinkers it appeared more than plausible that the relationship between the spirit-like life principle and the physical body has to be construed as a hierarchical order - in analogy to feudalism, royalism, or monotheism. Indeed, Hahnemann envisioned the life force as supplying life and order, enabling perception and self-preservation, exercising teleological instinct, etc. In short, as the autocratic ruler over the indigent, completely dependent organism. Accordingly, health is defined as the absolute domination of the life force over the material body. ${ }^{20}$

5. Hahnemann's writings do not confine themselves in medical topics in a narrow sense. His books and articles usually contain philosophical, anthropological, and ethical reflections as well. ${ }^{21}$ Like his contemporaries, Hahnemann believed in a high vocation of Man in the sense of being called to aspire to one's practical, cognitive, and spiritual perfection. ${ }^{22}$ To that purpose good health serves as a tool, ${ }^{23}$ health is seen as a potentiality for moral and intellectual growth.

6. Closely related to health as potentiality is the concept of health as transcendence. Although Hahnemann was neither a confessional dogmatic nor an active church-goer, he was religious in a freethinking, rational sense. In compliance with what was called "natural religion' as well as with Freemasonry (to which he adhered as a member), Hahnemann saw for instance the practice of medicine as a holy service at the altar of truth and the medical worshipper 'directly attaching oneself to the creator of the world'. While mental and moral imperfections, such as indolence, laziness, and stubbornness, prevent from achieving this goal, ${ }^{24}$ transcending and perfecting health from layer to layer in an ascending direction are the keys.

7. As a child of Enlightenment, Hahnemann was well disposed towards the idea of autonomy. Hence, apart from his professional books on therapeutics, he wrote many pamphlets and articles directed to a lay public trying to inform, educate, and enlighten the people on matters of hygiene, dietetics, and life style. ${ }^{25,26}$ Obviously, health is envisaged here as the result of rational and selfgoverning behaviour.

8. Living at the interface of two historic eras in terms of medical theory, Hahnemann's thinking was, in some respects, still bounded by traditional concepts, while in others, already reached out at the new scientific paradigm of causal-mechanical explanations. ${ }^{27}$ In his early medical writings he already spoke of 'animal machines', 'mainsprings' of 'clockworks', etc. Up to the last editions of his magnum opus, The Organon, he explained the mechanism of healing by the principle of similars with the supposition of a deterministic interaction between an alleged life force and medicinal agents. In the later editions, he relativized his phenomenological approach in homeopathic case taking in favour of his doctrine of miasms as the true causes of chronic diseases. ${ }^{28}$ Clearly, causal thinking also appealed to Hahnemann.

9. Public health plays an important role in Hahnemann's writings as well, especially in his early years. His advice and expertise on epidemiologic, forensic, and administrative issues show him as being inspired and driven by the thought that health indeed is an outcome of social-economic conditions and therefore also a matter for political decisions. ${ }^{29}$

10. From a systematic perspective, there is no single concept that stands out in Hahnemann's writings at the expense of the others. While in the early history of medicine paradigms were often advocated in an uncompromising, exclusive fashion, in Hahnemann's era it was already common to combine principles and methods of different theoretical approaches in more or less eclectic systems of medical practice. Also Hahnemann, being primarily a practitioner rather than a theorist, did not mind availing himself of a plurality of concepts including harmony, struggle, dialectics, hierarchy, potentiality, transcendence, autonomy, causality, and politics - as long as they proved to be useful tools in practice.

\section{Theory of medicine}

All the paradigms mentioned above can be traced in contemporary homeopathy as well, although mixed up in different schools and trends. Rather than teasing them out individually, some general remarks on the theory of medicine may suffice at this point.

Some authors deplore the splitting of post-modern homeopathy into a plurality of new schools. ${ }^{30}$ This indicates, however, that homeopathic doctors and health care professionals are still (or more than ever) struggling for a general theory of homeopathy that would: 1 . guide them in their practice, 2. explain to them what they are doing, and 3. satisfy their intellectual, moral, and spiritual needs. Since practitioners are human beings, they usually want to be satisfied on all three levels. 
In my new German edition of the Organon, ${ }^{31}$ therefore, three levels of content are extracted and distinguished: 1 . practical directions and maxims, 2. theoretical explanations and hypotheses, and 3. metaphysical foundations and premises, - thus providing a solid basis for further research. $^{32}$

The first level should be the easiest to settle. Judging of practical advice and guidelines should be empirical, based on clinical studies, and qualified evaluations. If anywhere, here it should be possible to reach a consensus, to demonstrate statistical evidence, or even to talk of something like practical truth or objectivity.

The third plane, the level of metaphysics, concerns the religious, philosophical, and ideologic fundamentals and individual idiosyncrasy. As experience shows, it is difficult if not impossible to persuade or convince anybody to modify or abandon his subjective world view. Not even (alleged) facts or scientific arguments seem to have a chance against personal conviction.

Between these extremes lies the second plane, the level of explanation or actual theory of medicine. This is the battleground of reformers, theorists, and systematists in the history of medicine. In this realm, between empirical findings and metaphysical beliefs, however, neither absolute objectivity nor total subjectivity, neither general determinism nor entire arbitrariness, neither plain uniformity nor complete relativity is expected. It is the vast field of the life sciences, of philosophy, of theory of science, etc. And it is the level, on which physicians, primarily have to reflect on the way they see themselves.

Depending on their inclinations and preferences, individual therapists may limit their interests to applying practical rules according to given laws that they have learned. Others may indulge in lofty speculations, thus becoming liable to disregard the empirical reality of their patients. Best balanced and most appropriate to academic doctors, however, would be the intermediate position. This, however, implies the readiness to accept the challenge of dispensing with the claim of absolute truth and, instead, adopt critical thinking. Thus, by theorizing, different paradigms of health can be reflected, combined, and elaborated.

Such an attempt, however, requires great self-criticism and self-reflection. Instead of naively believing in the possibility of ever standing on firm ground or of simply proceeding from unprejudiced observation to reliable knowledge, the theorist of medicine has to be aware that he is always starting from presuppositions that cannot be demonstrated in an absolute sense, that any system will always be incomplete, and that nobody will ever know what is beyond our models and theories.

Hahnemann took a similar view when he continually emphasized that the human cognitive faculty is limited. Leaning on Kant who epistemologically had defined the limits of pure, practical, and teleological reason, ${ }^{33-35}$ Hahnemann tried, as far as he could, to avoid notions without possible experience as well as para-empiricism without underlying principles. $^{36}$ His main mission was the establishment of a method of healing rather than a universal theory of medicine. This explains why he considered a consistent theory without contradiction less important than its practical utility. Hahnemann was, after all, not a philosopher.

\section{Conclusion}

All this has to be taken into account by those who try to develop, advocate, and promote homeopathy in the 21 st century. Claiming for instance that homeopathy directs patients towards better health rather than suppressing symptoms is certainly a promising approach, as it evokes positive associations and can connect to popular and trendy ideas, such as self-responsibility, holism, and salutogenesis. ${ }^{37}$ All the more so, as it relates to modern scientific paradigms, such as systems theory, cybernetics, and semiology, rather than on Cartesian linear-deterministic and causal-mechanical thinking. Nevertheless, one has to keep in mind that such endeavours are on the level of theory, mainly designed to facilitate social and political acceptance of homeopathy rather than to help or guide the practitioner, let alone to revitalise Hahnemann's practical instructions of how to cure the sick.

Certainly, in order to make his theory of disease and healing comprehensible to his colleagues, Hahnemann adopted contemporary concepts, such as life force, miasms, dynamic causes of diseases, dynamic action of remedies, signs and symptoms, etc. The need to use, as a tool, the 'scientific' language of one's time, however, does not allow the conclusion that, whenever a new discovery is made, the terms and conceptions prevailing at that time will necessarily be best suited to explain it. Hence, scientists of today should feel free to abandon nineteenth century terminology and try to conceptualize homeopathy in terms of psycho-neuro-endocrino-immunology, epigenetics, complexity, non-linearity, phenomenology, etc.

The same may apply to theoretical efforts to grasp with modern concepts what we today regard to be good health. As is shown by the arguments above, apart from differences in language and emphasis, the options in principle of how to think 'health' are limited in number. Thus, the challenge is rather to consider and balance the existing approaches in a useful way than to entirely create new ones. From this perspective, Hahnemann may serve less as an example of coining new terms, advocating temporary theories, and confronting conventional dogmas but rather of representing a relatively balanced view of all the dimensions concerning the issue of health, as well as disease and healing.

The fact that Hahnemann's therapeutic system has been practiced all over the world for nearly 200 years, strongly suggests that, although today some of his theoretical terms and concepts may be controversial or outdated, he found something practically relevant and beneficial. Distinguishing the levels of practice, theory and metaphysics opens up a vast horizon of theoretical reflections and at the same time guards against objections to homeopathy based solely on theoretical considerations. 


\section{References}

1 Unschuld PU. Chinese medicine. A history of ideas. Berkeley: University of California Press, 1985. Medizin in China. Eine Ideengeschichte. München: Beck, 1980.

2 Uexküll T, Wesiak W. Theorie der Humanmedizin. Grundlagen ärztlichen Denkens und Handelns. 3. Aufl. München: Urban \& Schwarzenberg, 1998.

3 Porter R. The greatest benefit to mankind. A medical history of humanity from antiquity to the present. London: Harper Collins Publishers, 1997. Die Kunst des Heilens. Eine medizinische Geschichte der Menschheit. Heidelberg: Spektrum Akademischer Verlag, 2000.

4 Stausberg M. Zarathustra und seine Religion. München: Beck, 2005.

5 Novalis. Fragment 190. In: Schulz G (ed). Werke. 2 Aufl. München: Beck, 1981, p 562.

6 Assmann J. Agypten. Eine Sinngeschichte. 2 Aufl. München, Wien: Fischer, 2000.

7 Schipperges H. Hildegard von Bingen. München: Beck, 1995, pp $69-72$.

8 Beyer R. Die andere Offenbarung. Mystikerinnen des Mittelalters. Wiesbaden: Fourier, 1996.

9 Bergdolt K. Arzt, Krankheit und Therapie bei Petrarca. Weinheim: VCH Acta Humaniora, 1992.

10 Shapin S. The scientific revolution. Chicago: University of Chicago Press, 1996.

11 Kant I. Metaphysik der Sitten (1797). A63-A115. In: Weischedel W (ed). Werke. Bd. 8. 5. Aufl. Frankfurt am Main: Suhrkamp, 1982, pp 549-583.

12 Büring M. Naturheilkunde. Grundlagen, Anwendungen, Ziele. München: Beck, 1997, p 113.

13 Jütte R. Geschichte der Alternativen Medizin. München: Beck, 1996.

14 Schmidt JM. Die Entstehung, Verbreitung und Entwicklung von Heilsystemen als Gegenstand der Medizingeschichte - am Beispiel der Homöopathie. [The origin, diffusion and development of healing doctrines in medical history - exemplified by homeopathy]. Sudhoffs Arch 2007; 91: 38-72.

15 Hahnemann S. Organon der Heilkunst. Textkritische Ausgabe der 6. Auflage. Schmidt JM (ed). Neuausgabe 1999. Stuttgart: Haug, 2002, p 23, $\S \S 11,29$.

16 Hahnemann S. Organon of the medical art. Decker S (Transl.), O'Reilly WB (ed). Redmond, Washington: Birdcage Books, 1996, $\S \S 9,16$.

17 Hahnemann S. Heilkunde der Erfahrung (1805). In: Hahnemann S, Schmidt JM, Kaiser D (eds). Gesammelte kleine Schriften [ $=G K S$ ]. Heidelberg: Haug, 2001, pp 387-417, here p 390.

18 Hahnemann S. Organon of the medical art. $\S \S 158,161,248,280$.
19 Hahnemann S. Organon of the medical art. $\S 141$.

20 Hahnemann S. Organon of the medical art. $\S \S 10,9$.

21 Schmidt JM. Believing in order to understand: Hahnemann's hierarchisation of values. Homeopathy 2008; 97: 156-160.

22 Hahnemann S. Heilkunde der Erfahrung (1805). In: $G K S$ (2001), p 389.

23 Hahnemann S. Organon of the medical art. $\S 9$.

24 Hahnmenan S. Organon der rationellen Heilkunde. Dresden: Arnold, 1810, pp iii-iv.

25 Hahnemann S. Freund der Gesundheit (1792, 1795). In: GKS (2001), pp 119-149, 171-173, 191-200.

26 Hahnemann S. Der Kaffee in seinen Wirkungen (1803). In: GKS (2001), pp 351-364.

27 Schmidt JM. Is homeopathy a science? - Continuity and clash of concepts of science within holistic medicine. $J$ Med Humanit $2009 ; 30: 83-97$.

28 Hahnemann S. Die chronischen Krankheiten, ihre eigenthümliche Natur und homöopathische Heilung. 4 Bde. Dresden und Leipzig: Arnold, 1828-1830. The chronic diseases, their peculiar nature and their homoeopathic cure. Tafel LH (Transl.), Philadelphia: Boericke \& Tafel, 1896.

29 Hahnemann S. Freund der Gesundheit (1795). In: GKS (2001), pp 174-190.

30 Habich K, Kösters C, Rohwer J. A step forward that makes sense - or a step back to the days before Hahnemann? An international discussion about modern trends, diversity of methods, and genuine homoeopathy, $<w w w . g r u n d l a g e n-p r a x i s . d e>$.

31 Hahnemann S. Organon der Heilkunst. Neufassung der 6. Auflage mit Systematik und Glossar. Schmidt JM (ed). 2nd edn. München Elsevier, 2006.

32 Schmidt JM. Hahnemann's legacy in a new light - A systematic approach to the Organon of Medicine. Homeopathy 2005; 94: $202-206$.

33 Kant I. Kritik der reinen Vernunft (1781). In: Weischedel W (ed). Werke. Bde. 3-4. Frankfurt am Main: Suhrkamp, 1974.

34 Kant I. Kritik der praktischen Vernunft (1788). In: Weischedel W (ed). Werke. Bd. 7. Frankfurt am Main: Suhrkamp, 1974, pp $103-302$

35 Kant I. Kritik der Urteilskraft (1790). In: Weischedel W (ed). Werke. Bd. 10. Frankfurt am Main: Suhrkamp, 1974, pp 69-456.

36 Hahnemann S. Heilkunde der Erfahrung (1805). In: GKS (2001), p 390.

37 Antonovsky A. Unraveling the mystery of health - how people manage stress and stay well. San Francisco: Jossey-Bass Publishers, 1987. Salutogenese. Zur Entmystifizierung der Gesundheit Tübingen: dgvt-Verlag, 1997. 